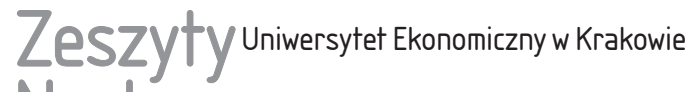 Naukowe
}

$8(932)$

ISSN 1898-6447

Zesz. Nauk. UEK, 2014; 8 (932): 79-91 DOI: 10.15678/ZNUEK.2014.0932.0806

Katarzyna Owsiak

Katedra Finansów Samorządowych

Uniwersytet Ekonomiczny w Krakowie

\section{Wydatki jednostek samorządu terytorialnego w Polsce w latach 2010-2013}

\section{Streszczenie}

Polityka wydatkowa samorządu terytorialnego jest przede wszystkim uwarunkowana rodzajami zadań publicznych, których realizacja jest przypisana do danej jednostki samorządu terytorialnego. Zadania te, a także źródła dochodów oraz ich wydajność, rozmiary deficytów budżetowych, poziom zadłużenia samorządów oraz zmieniające się otoczenie prawno-gospodarcze wpływają na strukturę wydatków. Wzrostowi wydatków bieżących w latach 2010-2013 towarzyszył spadek wydatków majątkowych od 2012 r., co wynikało przede wszystkim ze spadku wydatków inwestycyjnych o $16 \% \mathrm{w}$ porównaniu z $2011 \mathrm{r}$.

Od 2010 r. obowiązują przepisy nowej Ustawy z dnia 27 sierpnia 2009 r. o finansach publicznych. Jednocześnie w latach 2010-2013 system zasilania finansowego samorządów opierał się na Ustawie z dnia 13 listopada 2003 r. o dochodach jednostek samorządu terytorialnego, co interpretuje się jako stabilne zasady kształtowania się dochodów. Niemniej w tym okresie miały miejsce istotne nowelizacje wskazanych ustaw, a także wiele innych zmian legislacyjnych. Dlatego też celem artykułu jest przedstawienie wybranych aspektów polityki wydatkowej jednostek samorządu terytorialnego w Polsce w latach 2010-2013 na tle zmian przepisów prawa regulującego gospodarkę finansową jednostek samorządu terytorialnego i próba odpowiedzi na pytanie, czy te zmiany wpłynęły na strukturę wydatków.

Słowa kluczowe: wydatki jednostek samorządu terytorialnego, polityka wydatkowa, źródła dochodów, dotacje na zadania bieżące. 


\section{Wprowadzenie}

Problematyka dotycząca gospodarki finansowej jednostek samorządu terytorialnego (JST) ma wymiar zarówno ekonomiczny, jak i społeczny. Wydatki ponoszone przez JST przeznaczane są na zadania publiczne służące zaspokojeniu potrzeb społeczności lokalnej oraz regionalnej. Na strukturę wydatków wpływają zakres realizowanych zadań, źródła dochodów oraz ich wydajność, rozmiary deficytów budżetowych, poziom zadłużenia samorządów oraz zmieniające się otoczenie prawno-gospodarcze.

Od 2010 r. obowiązują przepisy nowej ustawy o finansach publicznych [Ustawa z dnia 27 sierpnia 2009 r. o finansach publicznych... 2009], co „,...) stanowi z jednej strony reakcję na wymogi bieżącego zarządzania środkami publicznymi, z drugiej natomiast jest wyrazem dążenia do zreformowania polskiego prawa finansowego w celu zwiększenia oszczędności oraz skuteczności i efektywności wykonywania zadań publicznych" [Sprawozdanie z działalności... 2011, s. 135]. Najogólniej modyfikacja przepisów związanych z gospodarką finansową JST dotyczyła następujących obszarów: form organizacyjno-prawnych; zaostrzenia procedury budżetowej, w tym nakazu zrównoważenia budżetu bieżącego (operacyjnego); limitacji zadłużenia; wprowadzenia kontroli zarządczej i wzmocnienia audytu wewnętrznego; wydłużenia horyzontu planowania wieloletniego poprzez wprowadzenie nowoczesnego instrumentu zarządzania finansami, jakim jest wieloletnia prognoza finansowa.

Jednocześnie w latach 2012-2013 system zasilania finansowego JST opierał się na ustawie o dochodach jednostek samorządu terytorialnego [Ustawa z dnia 13 listopada 2003 r. o dochodach jednostek samorządu terytorialnego... 2014], co interpretuje się jako stabilne zasady kształtowania się dochodów. Niemniej w tym okresie miały miejsce dwie istotne zmiany. Pierwsza z nich, dokonana w 2012 r., dotyczyła podatku dochodowego od osób fizycznych i polegała na obniżeniu progów podatkowych i wprowadzeniu ulgi z tytułu wychowania dzieci. Druga zmiana dokonana została na podstawie Wyroku Trybunału Konstytucyjnego z dnia 31 stycznia 2013 r. [2013] i dotyczyła zmiany zasad podziału rezerwy subwencji ogólnej.

Zmiany te miały wpływ ma kształtowanie wydatków jednostek samorządu terytorialnego. Dlatego też celem artykułu jest przedstawienie wybranych aspektów polityki wydatkowej jednostek samorządu terytorialnego w Polsce w latach 2010-2013 na tle zmian przepisów prawa regulującego gospodarkę finansową jednostek samorządu terytorialnego. Chodzi zwłaszcza o próbę odpowiedzi na pytanie, czy wprowadzone zmiany sprzyjają racjonalizacji wydatków JST. Istota (zasada) racjonalności wydatków władz samorządowych (publicznych) jest różnie określana w literaturze przedmiotu oraz w unormowaniach prawnych. Spełnieniu zasady racjonalnego wydatkowania środków publicznych mają służyć 
zapisy ustawy o finansach publicznych zawarte w rozdziale 5 ,Zasady gospodarowania środkami publicznymi" [Ustawa z dnia 27 sierpnia 2009 r. o finansach publicznych... 2009]. Zgodnie z art. 44 wydatki publiczne mogą być ponoszone na cele i w wysokościach określonych w uchwale budżetowej JST w sposób celowy i oszczędny, z zachowaniem zasad uzyskiwania najlepszych efektów z danych nakładów, a także optymalnego doboru metod i środków służących osiągnięciu założonych celów. Ustawowa interpretacja zasady racjonalności wydatków samorządowych jest jednak przedmiotem krytyki. Warunkiem racjonalności wydatków jest samodzielność decyzyjna władz samorządowych, a nie sprzyjają jej zapisy ustawy o finansach publicznych [Dylewski 2014]. W niniejszym opracowaniu podjęta została próba oceny tych zmian z perspektywy racjonalnego kształtowania wydatków samorządowych.

\section{Zmiany legislacyjne wpływające na gospodarkę budżetową jednostek samorządu terytorialnego}

Niezależnie od wskazanych zmian w latach 2010-2013 miały miejsce dalsze zmiany przepisów oddziałujące na gospodarkę finansową JST. Chodzi tutaj o zmiany w zakresie finansowania: oświaty, lokalnych inwestycji drogowych, kultury fizycznej oraz inwestycji komunalnych. W przypadku tych ostatnich dziedzin wiązało się to pozyskiwaniem przez gminy środków z Funduszu Rozwoju Kultury Fizycznej oraz Funduszu Rozwoju Inwestycji Komunalnych. W omawianym okresie zmieniały się wymogi związane ze sprawozdawczością budżetową i zasadami rachunkowości oraz zamówieniami publicznymi. Ponadto modyfikacji ulegały przepisy dotyczące sporządzania wieloletniej prognozy finansowej (WPF), tj. wykazu jej obligatoryjnych elementów wraz z rozszerzeniem objaśnień do niej, obowiązku elektronicznego przekazywania uchwał i zarządzeń w sprawie WPF do Ministerstwa Finansów. Od 1 stycznia 2012 r. zmieniono także sposób klasyfikacji tytułów dłużnych zaliczanych do długu publicznego; dla JST oznaczało to obowiązek zaliczania do długu kredytów i pożyczek nienazwanych czy kredytów handlowych.

$\mathrm{W}$ analizowanym okresie miały miejsce m.in. zmiany przepisów prawa nakładające na JST nowe obowiązki.

Jeżeli chodzi o zmiany legislacyjne, które miały miejsce w 2010 r., wymienić należy następujące [Sprawozdanie z działalności... 2011, s. 135-137]:

- stworzono możliwość otrzymywania dotacji celowych w zakresie kultury fizycznej poprzez określenie zasad uprawiania, organizowania i wspierania sportu, np. w klubach sportowych działających na terenie gminy, których celem nie jest osiąganie zysku; 
- wprowadzono możliwość ustanawiania i finansowania przez JST okresowych stypendiów sportowych oraz nagród i wyróżnień dla osób fizycznych za osiągnięte wyniki sportowe;

- umożliwiono świadczenie przez JST usług dostępu do Internetu bez pobierania opłat lub w zamian za opłatę niższą niż cena rynkowa.

Z kolei w 2011 r. wprowadzone zostały następujące zmiany [Sprawozdanie zdziałalności... 2012, s. 146-148]:

- wprowadzono nowe przepisy, na mocy których inwestycje z zakresu ochrony środowiska mogą być dotowane bezpośrednio z budżetu gminy lub powiatu podmiotom niezaliczonym do sektora finansów publicznych (także osobom fizycznym) realizującym inwestycje prywatne;

- przeprowadzono reformę systemu opieki nad dziećmi do lat 3, która może być zorganizowana w formie żłobka lub klubu dziecięcego (jako gminna jednostka budżetowa), a także sprawowana przez opiekuna dziennego lub nianię (dalsze zmiany w tym zakresie miały miejsce w 2013 r.);

- znowelizowano dwukrotnie ustawę o podatkach i opłatach lokalnych [Ustawa z dnia 24 września 2010 r. o zmianie ustawy o podatkach i opłatach lokalnych... 2010, Ustawa z dnia 15 kwietnia 2011 r. o zmianie ustawy o podatkach i opłatach lokalnych... 2011]. Na mocy pierwszej nowelizacji gminy zostały zobligowane do stosowania obniżonej stawki podatku od nieruchomości związanych z prowadzeniem działalności gospodarczej w zakresie udzielania świadczeń zdrowotnych, zajętych przez podmioty udzielające tych świadczeń. Na mocy kolejnej nowelizacji nie pobiera się opłaty targowej od sprzedaży dokonywanej w budynkach, także tych służącym targom;

- przekazane zostało samorządom od dnia 1 marca 2011 r. nowe zadanie z zakresu transportu publicznego, a także przyjęta została ustawa o działalności leczniczej [Ustawa z dnia 15 kwietnia 2011 r. o działalności leczniczej... 2011] dająca samorządom możliwość przekształcenia samodzielnych publicznych zakładów opieki zdrowotnej nadzorowanych przez JST w spółkę kapitałową (spółkę z ograniczoną odpowiedzialnością lub spółkę akcyjną).

W 2012 r. rozszerzono zakres zadań JST i organów administracji rządowej w kwestii wspierania rodziny i organizacji systemu pieczy zastępczej, co w praktyce oznacza nowe zadania zlecone i własne. Zmianie uległy także zadania własne gmin w zakresie zapewnienia opieki bezdomnym zwierzętom, w tym uchwalania programu opieki nad zwierzętami bezdomnymi oraz zapobiegania bezdomności zwierząt [Sprawozdanie z działalności... 2013, s. 141-142].

W 2013 r. znowelizowano ustawę o systemie oświaty, wprowadzając nowe sposoby finansowania i funkcjonowania przedszkoli, w myśl zasady, że każde dziecko w wieku od 3 do 5 lat będzie mogło korzystać z wychowania przedszkolnego, o ile rodzice wyrażą taką wolę. Rok ten oznaczał kontynuację tzw. rewolucji 
śmieciowej, zgodnie z którą zmienione zostały zasady dotyczące systemu gospodarowania odpadami. Pierwszy etap zmian miał miejsce w 2012 r., polegał on na wprowadzeniu obowiązku podjęcia przez gminy uchwał zawierających nowe zasady odbierania odpadów od mieszkańców, w tym określenia stawek, oraz nowe regulaminy utrzymania czystości i porządku itp. Kolejna nowelizacja miała na celu usprawnienie istniejących rozwiązań, chociażby poprzez wprowadzenie e-deklaracji [Sprawozdanie z działalności... 2014, s. 172-173].

\section{Zmiany w źródłach dochodów jednostek samorządu terytorialnego}

Głównym celem artykułu jest przedstawienie wpływu zmian o charakterze legislacyjnym (systemowym) na wielkość oraz strukturę wydatków. Analiza strony wydatkowej budżetów samorządowych w oderwaniu od kształtowania się strony dochodowej w obserwowanym okresie byłaby niepełna, tym bardziej że w okresie tym pojawiały się zmiany w systemie dochodów. Stąd też w niniejszym punkcie przedstawiona została charakterystyka ogólnej struktury dochodów JST w latach 2010-2013.

W strukturze dochodów JST w analizowanym okresie dochody własne stanowiły 48,3\% dochodów ogółem w 2010 r., 48,8\% w 2011 r., 49,1\% w 2012 r., a 50,0\% w 2013 r. Z zestawienia zaprezentowanego w tabeli 1 wynika, że najbardziej wydajnym fiskalnie źródłem dochodów własnych od lat są wpływy z udziałów w podatku dochodowym od osób fizycznych i wpływy z podatku od nieruchomości. W kolejnych latach udział podatku dochodowego od osób fizycznych wyniósł 34,2\%, 35,2\%, a w latach 2012 i 2013 35,4\%. Wielkość udziału we wpływach z podatku dochodowego od osób fizycznych ulegała zmianie w gminach i wynosiła 36,94\% w 2010 r., 37,12\% w 2011 r., 37,26\% w 2012 r. i $37,42 \%$ w 2013 r. W pozostałych jednostkach udział kształtował się na tym samym poziomie - dla powiatów $10,25 \%$, dla województw samorządowych $1,60 \%$. Udział we wpływach z podatku dochodowego od osób prawnych wynosił w badanym okresie odpowiednio: dla gmin $6,71 \%$, dla powiatów $1,40 \%$, a dla województw samorządowych $14,75 \%$. Natomiast udział podatku od nieruchomości w dochodach własnych wynosił 19,2\% w 2010 r., 19,4\% w 2011 r., 20,2\% w 2012 r., a 20,4\% w 2013 r. Na mocy art. 168 konstytucji [Konstytucja Rzeczypospolitej Polskiej... 1997] gminy i miasta na prawach powiatu mają prawo do ustalania wysokości podatków i opłat lokalnych (regulacja stawek podatkowych w ramach upoważnień określonych przez obowiązujące ustawy), a także mogą decydować o zastosowaniu niektórych preferencji podatkowych (ulgi podatkowe, zwolnienia od podatku, odroczenie terminu płatności, rozłożenie płatności podatku na raty, 
umorzenie zaległości podatkowych itp.). Uprawnienia te dają gminom i miastom na prawach powiatu możliwość kreowania polityki dochodowej, a także rozwojowej (inwestycyjnej). Według obliczeń Ministerstwa Finansów [Sprawozdanie z wykonania budżetu państwa... 2011, 2012, 2013,2014] w wyniku obniżenia górnych stawek podatków, udzielenia ulg i zwolnień (bez ustawowych) oraz podjęcia decyzji o umorzeniu, rozłożeniu na raty i odroczeniu terminu płatności do budżetów gmin nie wpłynęła kwota: w 2010 r. - 3,05 mld zł, w 2011 r. 3,1 mld zł, w 2012 r. - 3,8 mld zł, w 2013 r. - 4,0 mld zł. Stanowi to od 4,2\% dochodów ogółem i 9,5\% dochodów własnych w 2010 r. do 5\% dochodów ogółem i 10,4\% dochodów własnych w 2013 r. W przypadku miast na prawach powiatu kwota ta wynosiła 7,1 mln zł w 2010 r., 7,5 mln zł w 2011 r., 6,5 mln zł w 2012 r. i 6,8 mln zł w 2013 r. Obniżanie górnych stawek podatków lokalnych stanowi główny powód ograniczania wpływów do budżetów gmin i miast na prawach powiatu z tytułu konstytucyjnych uprawnień w zakresie podatków i opłat lokalnych, co stanowi od 65\% do 78\% w gminach i w zmiennej kolejności od 60\% do $68 \%$ w miastach na prawach powiatu, przy czym podatek od nieruchomości dominuje w większości form wynikających z tzw. lokalnego władztwa podatkowego. Tylko dogłębne badania mogłyby dać odpowiedź na pytanie, do jakiego stopnia uprawnienia te są wykorzystywane jako instrument kreacji rozwoju lokalnego, a w jakim są wymuszone przez sytuację gospodarczą.

Tabela 1. Dochody jednostek samorządu terytorialnego w latach 2010-2013 (mld zł)

\begin{tabular}{|l|c|c|c|c|}
\hline \multicolumn{1}{|c|}{ Dochody JST } & 2010 & 2011 & 2012 & 2013 \\
\hline Dochody ogółem & 162,8 & 171,3 & 177,4 & 183,5 \\
\hline 1. Dochody własne, w tym: & 78,6 & 83,6 & 87,1 & 91,8 \\
\hline 1.1. podatek od nieruchomości & 15,1 & 16,2 & 17,6 & 18,7 \\
\hline 1.2. podatek dochodowy od osób prawnych & 6,1 & 6,9 & 6,8 & 6,3 \\
\hline 1.3. podatek dochodowy od osób fizycznych & 26,9 & 29,4 & 30,8 & 32,5 \\
\hline 2. Subwencja ogólna, w tym: & 47,2 & 48,3 & 50,6 & 51,3 \\
\hline 2.1. część oświatowa & 35,0 & 36,9 & 39,2 & 39,5 \\
\hline 3. Dotacje celowe, w tym: & 25,8 & 26,1 & 25,2 & 26,4 \\
\hline 3.1. na zadania z zakresu administracji rządowej & 16,8 & 16,5 & 16,7 & 16,8 \\
\hline 3.2. na zadania własne & 6,9 & 6,9 & 5,7 & 6,9 \\
\hline Dotacje na podstawie paragrafów 200 i 620 & 11,2 & 13,3 & 14,5 & 14,4 \\
\hline
\end{tabular}

${ }^{a}$ Dotacje na podstawie paragrafów 200 i 620 zastąpiły dotacje rozwojowe i obejmują dotacje celowe w ramach programów finansowanych $\mathrm{z}$ udziałem środków europejskich oraz innych środków zagranicznych niepodlegających zwrotowi lub płatności w ramach budżetu środków europejskich.

Źródło: opracowanie własne na podstawie [Sprawozdanie z wykonania budżetu państwa... 2011, 2012, 2013, 2014]. 
Subwencja ogólna składa się z części oświatowej, wyrównawczej, równoważącej, regionalnej i rekompensującej. Część rekompensująca przyznana jest gminom i miastom na prawach powiatu w związku z ubytkiem dochodów na skutek preferencji podatkowych przyznanych przedsiębiorcom, którzy prowadzą działalność gospodarczą na terenie specjalnych stref ekonomicznych. Ponadto tworzy się rezerwę subwencji ogólnej dla JST, którą dysponuje minister finansów w porozumieniu z reprezentacją JST. Wspomniany w punkcie 1 artykułu Wyrok Trybunału Konstytucyjnego z dnia 31 stycznia 2013 r. [2013] dotyczył podziału kwoty tej rezerwy - sposobu przeznaczenia i określenia kryteriów, co znalazło wyraz w nowelizacji ustawy o dochodach jednostek samorządu terytorialnego [Ustawa z dnia 13 grudnia 2013 r. o zmianie ustawy... 2013]. Przyjęcie tego rozwiązania jest wyrazem wzmocnienia mechanizmu korekcyjno-wyrównawczego części dochodów JST.

Kolejna planowana zmiana w ustawie o dochodach jednostek samorządu terytorialnego wiąże się z Wyrokiem Trybunału Konstytucyjnego z 4 marca 2014 r. [2014], odnoszącym się do kwestii mechanizmu wyrównawczego powstającego w ramach części równoważącej subwencji ogólnej, tzw. janosikowym. Trybunał orzekł, że art. 31 i art. 25 wskazanej ustawy o dochodach jednostek samorządu terytorialnego nie są zgodne $\mathrm{z}$ konstytucją w zakresie, $\mathrm{w}$ jakim nie gwarantują województwom samorządowym zachowania istotnej części dochodów własnych dla realizacji zadań własnych.

\section{Struktura wydatków jednostek samorządu terytorialnego}

Lata spowolnienia gospodarczego wpłynęły na system zasilania JST, powodując od 2009 r. spadek udziału dochodów własnych w strukturze dochodów ogółem, co zaczyna się nieznacznie zmieniać od 2012 r. (zob. tabela 1). Na poziom wydatków wpływa też liczba przekazywanych nowych zadań. Na podstawie szacunków Związku Miast Polskich od 2000 r. polskim JST przybyło ok. 60 nowych zadań, co oznacza, że ich realizacja wymaga dodatkowo rocznie ponad 8 mld zł [Poniatowicz 2013].

Wzrostowi wydatków bieżących w latach 2010-2013 towarzyszył spadek wydatków majątkowych od 2012 r., co wynikało przede wszystkim ze spadku wydatków inwestycyjnych o 16\% w porównaniu z 2011 r. (tabela 2).

Na podstawie danych zawartych w wieloletnich prognozach finansowych przesłanych do Ministerstwa Finansów (stan na 19 sierpnia 2013 r.) przewidywany jest spadek wydatków ogółem (stan na 2014 r. - 186 mld zł, 174 mld zł w 2015 r. i 171 mld zł w 2016 r.). Wydatki majątkowe będą kształtowały się na następującym poziomie: w 2014 r. - 37,0 mld zł, w 2015 r. - 24,0 mld zł, a w 2016 r. - 
18,7 mld zł (http://www.mf.gov.pl/documents/766655/5849707/zestawienia, dostęp: 25.04.2014).

Tabela 2. Wydatki JST w latach 2010-2013 (mld zł)

\begin{tabular}{|l|c|c|c|c|}
\hline \multicolumn{1}{|c|}{ Wydatki JST } & 2010 & 2011 & 2012 & 2013 \\
\hline Wydatki ogółem & 177,7 & 181,6 & 180,5 & 183,8 \\
\hline 1. Wydatki bieżące, w tym: & 133,5 & 139,2 & 144,8 & 148,8 \\
\hline 1.1. wydatki na wynagrodzenia & 49,7 & 54,1 & 56,1 & 57,0 \\
\hline 1.2. pochodne od wynagrodzeń & 8,2 & 8,9 & 10,1 & 10,5 \\
\hline 1.3. dotacje & 14,0 & 13,5 & 14,2 & 14,9 \\
\hline 1.4. wydatki na obsługę długu & 1,9 & 2,7 & 3,5 & 2,8 \\
\hline 1.5. wydatki z tytułu udzielania poręczeń i gwarancji & 0,09 & 0,08 & 0,06 & 0,05 \\
\hline 1.6. świadczenia na rzecz osób fizycznych & 16,6 & 16,0 & 16,2 & 16,8 \\
\hline 1.7. pozostałe wydatki & 43,1 & 43,9 & 44,7 & 46,8 \\
\hline 2. Wydatki majątkowe, w tym: & 44,2 & 42,4 & 35,7 & 35,0 \\
\hline 2.1. wydatki na inwestycje & 43,3 & 41,2 & 34,4 & 33,5 \\
\hline
\end{tabular}

Źródło: jak w tabeli 1.

Tabela 3. Struktura wydatków bieżących i majątkowych w latach 2010-2013 według typów JST

\begin{tabular}{|l|c|c|c|c|}
\hline \multicolumn{1}{|c|}{ Wydatki JST } & 2010 & 2011 & 2012 & 2013 \\
\hline Wydatki ogółem & 100,0 & 100,0 & 100,0 & 100,0 \\
\hline \multicolumn{4}{|c|}{ 1. Wydatki bieżące } \\
\hline Gminy & 74,9 & 77,1 & 81,9 & 83,4 \\
\hline Miasta na prawach powiatu & 77,7 & 78,8 & 80,1 & 80,9 \\
\hline Powiaty & 78,2 & 81,3 & 87,5 & 87,5 \\
\hline Województwa & 61,0 & 59,5 & 62,2 & 60,3 \\
\hline \multicolumn{5}{|l|}{} \\
\hline Gminy & 25,1 & 22,9 & 18,1 & 16,6 \\
\hline Miasta na prawach powiatu & 22,3 & 21,2 & 19,9 & 19,1 \\
\hline Powiaty & 21,8 & 18,7 & 12,5 & 12,5 \\
\hline Województwa & 39,0 & 40,5 & 37,8 & 39,7 \\
\hline
\end{tabular}

Źródło: jak w tabeli 1.

W odniesieniu do zadań wykonywanych przez JST w badanym okresie w strukturze wydatków ujętych według działów klasyfikacji budżetowej dominowały cztery działy: oświata i wychowanie (28,4\% w 2010 r., 29,2\% w 2011 r., 
30,8\% w 2012 r., 30,6\% w 2013 r.), transport i łączność (18,0\% w 2010 i 2011 r., 16,3\% w 2012 r. i 16,4\% w 2013 r.), pomoc społeczna (ponad 12\%) i administracja publiczna (ok. 9\%), co łącznie stanowiło 67,3\% w 2010 r. i 68,9\% w 2013 r. wydatków ogółem [Sprawozdanie z wykonania budżetu państwa... 2011, 2012, 2013, 2014].

Strukturę wydatków według typów JST przedstawiono w tabeli 3. Można zauważyć, że najwięcej wydatków bieżących dokonują powiaty, a w przypadku wydatków majątkowych są to województwa samorządowe.

\section{Dotacje na zadania bieżące $\mathrm{z}$ budżetów JST jako szczególna forma wydatków}

Dotacje na zadania bieżące JST stanowią jeden z elementów polityki wydatkowej, są one ujęte w wydatkach bieżących. Przyjmuje się, że z jednej strony polityka dotacyjna JST jest rezultatem zapisów zawartych w ustawach co do realizacji zadań powierzonych, a z drugiej - struktura kwot dotacji na zadania bieżące ujęta zgodnie z klasyfikacją budżetową (w układzie działów i rozdziałów) odzwierciedla rodzaje tychże zadań na poszczególnych szczeblach JST. Wydatków na dotacje na zadania bieżące dotyczy duża liczba przepisów, co więcej, istnieją rozbieżności w ich interpretacji.

Zgodnie z zapisami ustawy o finansach publicznych [Ustawa z dnia 27 sierpnia 2009 r. o finansach publicznych... 2014, art. 218-221] dotacje stanowiące środki z budżetu JST podlegają szczególnym zasadom rozliczania i mogą być udzielane w formie:

1) dotacji podmiotowych, o ile odrębne ustawy tak stanowią,

2) dotacji przedmiotowych dla samorządowych zakładów budżetowych, kalkulowanych według stawek jednostkowych,

3) dotacji przedmiotowych dla innych podmiotów niż samorządowe zakłady budżetowe, o ile odrębne przepisy tak stanowią,

4) dotacji celowych dla innych jednostek samorządu terytorialnego jako pomoc finansowa lub pomoc rzeczowa,

5) dotacji celowych dla podmiotów niezaliczanych do sektora finansów publicznych i niedziałających w celu osiągnięcia zysku, związanych z realizacją zadań tej jednostki, a także na dofinansowanie inwestycji związanych z realizacją tych zadań.

W wydatkach ogółem wydatki na dotacje na zadania bieżące stanowią w analizowanym okresie ok. 8\% (tabela 4). Największy udział tego rodzaju wydatków w wydatkach ogółem zauważyć można w województwach samorządowych w odniesieniu do analizowanych lat kształtowały się one na poziomie odpowiednio 
$22,9 \%, 23,0 \%, 24,55 \%$ i 24,1\%. Analizując ogólną kwotę wydatków wszystkich JST na dotacje na zadania bieżące, można stwierdzić, że ok. 5 mld zł przypada na miasta na prawach powiatu [Sprawozdanie z wykonania budżetu państwa... 2011, 2012, 2013, 2014].

Tabela 4. Udział wydatków na dotacje na zadania bieżące w wydatkach ogółem JST w latach 2010-2013 (\%)

\begin{tabular}{|l|c|c|c|c|}
\hline \multicolumn{1}{|c|}{ Wydatki JST } & 2010 & 2011 & 2012 & 2013 \\
\hline Wydatki ogółem & 100,0 & 100,0 & 100,0 & 100,0 \\
\hline Wydatki na dotacje na zadania bieżące & 7,9 & 7,4 & 7,9 & 8,1 \\
\hline
\end{tabular}

Źródło: jak w tabeli 1.

Zgodnie z badaniami przeprowadzonymi przez Biuro Analiz Sejmowych [Korolewska 2014] w latach 2010-2013 około połowa zbiorczej kwoty dotacji przeznaczona została na dotacje podmiotowe dla samorządowych instytucji kultury (28,54\% w 2010 r., 30,62\% w 2011 r., 29,64\% w 2012 r., 28,57\% w 2013 r.) i na dotacje podmiotowe dla niepublicznych jednostek systemu oświaty $(16,23 \%$ w 2010 r., 19,46\% w 2011 r., 21,75\% w 2012 r., 23,00\% w 2013 r.). Oświata jest jeszcze dodatkowo dofinansowana dotacjami podmiotowymi dla publicznych jednostek oświaty prowadzonych przez osoby prawne inne niż jednostki samorządu terytorialnego lub przez osoby fizyczne (3,36\% w 2010 r., 3,95\% w 2011 r., 4,42\% w 2012 r., 5,17\% w 2013 r.). Tak wysoki udział w dotacjach na zadania bieżące dotacji z zakresu kultury i oświaty wynika z zapisów następujących ustaw o organizowaniu i prowadzeniu działalności kulturalnej: Ustawy z dnia 25 października 1991 r. o organizowaniu i prowadzeniu działalności kulturalnej [2014] i Ustawy z dnia 7 września 1991 r. o systemie oświaty [2014]. Wzrost wydatków w zakresie oświaty i wychowania wiąże się z częstymi zmianami legislacyjnymi.

\section{Podsumowanie}

Polityka wydatkowa samorządu terytorialnego jest uwarunkowana rodzajami zadań publicznych, które są przypisane do realizacji danej JST. Nadana zapisami konstytucyjnymi zasada samodzielności finansowej, w tym wydatkowej, jest uzależniona od kilku czynników, tj. obowiązku ponoszenia określonych wydatków związanego z wykonywaniem zadań przypisanych ustawowo, zakazów lub limitów ponoszenia wydatków, zasad udzielania dotacji z budżetów JST, standardów wykonywania zadań, standardów sposobu finansowania zadań poprzez dotacje celowe, gwarancji samodzielnego podejmowania decyzji przez organy JST 
w zakresie ponoszenia wydatków oraz zasad prowadzenia gospodarki budżetowej [Jastrzębska 2012, s. 139].

Analizę wydatków JST w badanym okresie należy uzupełnić wskazaniem nowych rozwiązań związanych z rezerwami celowymi, wydatkami niewygasającymi oraz funduszem sołeckim.

$\mathrm{Z}$ racji istnienia nadzoru nad gospodarką finansową JST należy wspomnieć o roli regionalnej izby obrachunkowej w procedurze budżetowej, a także przygotowaniu projektów uchwał oraz uchwał i zarządzeń w sprawie wieloletniej prognozy finansowej lub jej zmian. Można mówić także o bieżącym monitorowaniu kondycji finansowej JST poprzez istniejący od 2013 r. obowiązek elektronicznego przekazywania uchwał i zarządzeń w sprawie wieloletniej prognozy finansowej do Ministerstwa Finansów. Dane dotyczące dochodów, wydatków, wyniku budżetu, przychodów, rozchodów i długu jednostek samorządu terytorialnego przekazywane są pięć razy w ciągu roku budżetowego.

Wprowadzone reguły fiskalne, istniejący od 2010 r. obowiązek równoważenia budżetu w części bieżącej i wprowadzony w 2014 r. indywidualny wskaźnik zadłużenia [Ustawa z dnia 27 sierpnia 2009 r. o finansach publicznych... 2009, art. 242-244], a także tendencja do wzmocnienia bezpieczeństwa finansów publicznych przyczyniły się do kolejnej nowelizacji ustawy o finansach publicznych [Ustawa $\mathrm{z}$ dnia 8 listopada 2013 r. o zmianie ustawy o finansach publicznych... 2013], na mocy której dodano art. 240a związany z restrykcjami nałożonymi na skutek nieuchwalenia wieloletniej prognozy finansowej lub budżetu zgodnie z wymogami wynikającymi z zapisów art. 242-244. W praktyce oznacza to obowiązek przygotowania programu naprawczego przez JST na wezwanie regionalnej izby obrachunkowej, na okres nieprzekraczający trzech kolejnych lat budżetowych, zawierającego analizę stanu finansów JST, plan przedsięwzięć naprawczych oraz przewidywane efekty finansowe. Istotne jest to, że organ stanowiący musi wskazać przyczyny zagrożenia realizacji zadań publicznych, a w czasie trwania programu naprawczego JST nie może: podejmować nowych inwestycji finansowanych środkami zwrotnymi (kredytami i pożyczkami), udzielać pomocy finansowej innym JST, ponosić wydatków na promocję jednostki, tworzyć funduszu sołeckiego, a także ogranicza realizację zadań innych niż obligatoryjne, finansowanych ze środków własnych.

Konkludując, należy stwierdzić, że w analizowanym okresie dokonywane zmiany legislacyjne wiązały się z zakresem zadań publicznych realizowanych przez JST, a także były wynikiem podjętych działań ograniczających skutki kryzysu finansowego. W kontekście polityki wydatkowej JST można mówić o dwóch jej aspektach, uelastycznieniu wiążącym się z samodzielnością i usztywnieniu przez niekiedy restrykcyjne regulacje prawne. Temat polityki wydatkowej JST wymaga jednak pogłębionych badań, które dałyby pełniejszy obraz przekła- 
dania się omawianych zmian na strukturę wydatków poszczególnych rodzajów JST. Można jednak stwierdzić, że ilość zmian nie sprzyja racjonalizacji wydatków.

\section{Literatura}

Dylewski M. [2014], Problemy polityki wydatkowej jednostek samorzadu terytorialnego w świetle uwarunkowań prawnych i ekonomicznych, ,Finanse Komunalne”, nr 1-2.

Jastrzębska M. [2012], Finanse samorzadu terytorialnego, Lex a Wolters Kluwer Business, Warszawa.

Konstytucja Rzeczypospolitej Polskiej z dnia 2 kwietnia 1997 r., Dz.U. nr 78, poz. 483.

Korolewska M. [2014], Dotacje na zadania bieżace z budżetów jednostek samorzadu terytorialnego, „Analizy BAS”, nr 9(113), Biuro Analiz Sejmowych, Warszawa.

Poniatowicz M. [2013], Realizacja nowych zadań kosztuje samorzady rocznie ponad $8 \mathrm{mld} z$, http://www.obserwatorfinansowy.pl/forma/rotator/realizacja-dodatkowychzadan-bedzie-kosztowac-samorzady-co-najmniej-8-mld-zl/, dostęp: 25.04.2014.

Sprawozdanie z działalności Regionalnych Izb Obrachunkowych $i$ wykonania budżetu przez jednostki samorzadu terytorialnego w 2010 roku [2011], Krajowa Rada Regionalnych Izb Obrachunkowych, Warszawa.

Sprawozdanie z działalności Regionalnych Izb Obrachunkowych $i$ wykonania budżetu przez jednostki samorzadu terytorialnego w 2011 roku [2012], Krajowa Rada Regionalnych Izb Obrachunkowych, Warszawa.

Sprawozdanie z działalności Regionalnych Izb Obrachunkowych $i$ wykonania budżetu przez jednostki samorzadu terytorialnego w 2012 roku [2013], Krajowa Rada Regionalnych Izb Obrachunkowych, Warszawa.

Sprawozdanie z działalności Regionalnych Izb Obrachunkowych $i$ wykonania budżetu przez jednostki samorzadu terytorialnego w 2013 roku [2014], Krajowa Rada Regionalnych Izb Obrachunkowych, Warszawa.

Sprawozdanie z wykonania budżetu państwa za okres od 1 stycznia do 31 grudnia $2010 \mathrm{r}$. Informacja o wykonaniu budżetów jednostek samorzadu terytorialnego [2011], Rada Ministrów, Warszawa.

Sprawozdanie z wykonania budżetu państwa za okres od 1 stycznia do 31 grudnia 2011 r. Informacja o wykonaniu budżetów jednostek samorzadu terytorialnego [2012], Rada Ministrów, Warszawa.

Sprawozdanie z wykonania budżetu państwa za okres od 1 stycznia do 31 grudnia 2012 r. Informacja o wykonaniu budżetów jednostek samorzadu terytorialnego [2013], Rada Ministrów, Warszawa.

Sprawozdanie z wykonania budżetu państwa za okres od 1 stycznia do 31 grudnia 2013 r. Informacja o wykonaniu budżetów jednostek samorzadu terytorialnego [2014], Rada Ministrów, Warszawa.

Ustawa z dnia 7 września 1991 r. o systemie oświaty, Dz.U. nr 95, poz. 425 z późn. zm.

Ustawa z dnia 25 października 1991 r. o organizowaniu i prowadzeniu działalności kulturalnej, Dz.U. nr 114, poz. 493 z późn. zm.

Ustawa z dnia 13 listopada 2003 r. o dochodach jednostek samorządu terytorialnego, Dz.U. z 2014 r., poz. 1115, 1574, 1644.

Ustawa z dnia 27 sierpnia 2009 r. o finansach publicznych, Dz.U. nr 157, poz. 1240 z późn. zm. 
Ustawa z dnia 24 września 2010 r. o zmianie ustawy o podatkach i opłatach lokalnych, Dz.U. nr 225, poz. 1461.

Ustawa z dnia 15 kwietnia 2011 r. o zmianie ustawy o podatkach i opłatach lokalnych, Dz.U. nr 102, poz. 584.

Ustawa z dnia 15 kwietnia 2011 r. o działalności leczniczej, Dz.U. nr 112, poz. 654 z późn. zm.

Ustawa z dnia 8 listopada 2013 r. o zmianie ustawy o finansach publicznych, Dz.U. poz. 1646.

Ustawa z dnia 13 grudnia 2013 r. o zmianie ustawy o dochodach jednostek samorządu terytorialnego, Dz.U. poz. 1609.

Wieloletnia prognoza finansowa (WPF) jednostek samorządu terytorialnego na lata 2013-2016 (według stanu na 19.08.2013 r.), http://www.mf.gov.pl/documents/ 766655/5849707/zestawienia, dostęp: 25.04.2014.

Wyrok Trybunału Konstytucyjnego z dnia 31 stycznia 2013 r., sygn. akt K14/11, sentencja ogłoszona dnia 11 lutego 2013 r., Dz.U. poz. 193.

Wyrok Trybunału Konstytucyjnego z dnia 4 marca 2014 r., sygn. akt K13/11, Dz.U. poz. 348.

\section{The Expenditure of Local Government Units in Poland in 2010-2013}

The politics of local government spending is primarily determined by the types of public tasks assigned to local government units. These tasks, as well as sources of income and their performance, the size of budget deficits, the level of indebtedness of local government units and the changing economic and legal environment affect the structure of expenditure. The rise in current expenditure in 2010-2013 was accompanied by a decline in capital expenditure from 2012, which resulted primarily from a decrease of $16 \%$ in capital expenditure compared to 2011. The provisions of the new law of 27 August 2009 on Public Finances have been in force since 2010. At the same time, in 2010-2013, the financial self-supply system was based on the Act of 13 November 2003 on the income of local government units, which is interpreted as the source of stable regulation for income formation. Nevertheless, during this period there have been significant amendments to the cited statutes, as well as many other legislative changes. Therefore, the aim of this article is 1) to present selected aspects of the expenditure policy of local government units in Poland in the years 2010-2013 against the background of the law governing the financial management of local government units and 2) to attempt to answer the question of whether these changes have affected spending patterns.

Keywords: expenditure of local government units, spending policy, sources of income, subsidies on current tasks. 